\title{
O Tratado do belo ou as Indagações sobre a origem e a natureza do belo 1752 e alguns dos seus desdobramentos nos salons de 1763, 1765 e 1767 (e nos ensaios sobre a pintura que completam o salons 1765)

\author{
Alguns escritos de Denis Diderot \\ sobre o belo e as artes
}

\author{
Frédéric René Guy Petitdemange*
}

\begin{abstract}
Resumo Esse trabalho busca esclarecer alguns aspectos da reflexão estética do filósofo Denis Diderot aproximando $O$ Tratado do Belo ou as Indagações sobre as origens e a natureza do Belo com uma escolha de passagens dos Relatórios dos Salons. O Tratado foi editado como verbete sobre o Belo para a Encyclopédie em 1752. É um "tratado" tanto pelo estilo doutrinal empregado pelo filósofo, quanto pelo método epistemológico que busca nas suas origens a natureza do Belo. Os relatórios dos Salons de 1759,1763, 1765 e 1767, e os Ensaios sobre a pintura de 1765, constituíam os escritos mais importantes sobre a arte de Denis Diderot. Neles, o filósofo aplica e questiona na prática da crítica de Arte suas teorias em (trans) formações.
\end{abstract}

Palavras-chave: Diderot, história da arte, critica de arte.

El Tratado de belleza o las preguntas sobre el origen y la naturaleza del belo 1752 y algunos de sus desarrollos en los salones de 1763, 1765 y 1767 (y en los ensayos sobre la pintura que completan los salones 1765). Algunos escritos de Denis Diderot sobre lo bello y las artes

\footnotetext{
Resumen Este trabajo busca aclarar algunos aspectos de la reflexión estética del filósofo Denis Diderot, al relacionar el Tratado de lo Bello con una selección de pasajes de los Informes de los Salons. El Tratado fue publicado como una apostilla sobre lo bello en la Encyclopédie en 1752. Es un "tratado" tanto por el estilo doctrinal utilizado por el filósofo como por el método epistemológico que busca en sus orígenes la naturaleza de lo Bello. Los informes de los Salons y los Ensayos sobre la pintura de 1765 constituyeron los escritos más importantes sobre el Arte de Diderot. En estos comentarios, el filósofo emplea y cuestiona en la práctica de la crítica del Arte sus teorías en (trans) formaciones. Palabras clave: Diderot, historia del arte, crítica de arte.
}

The Treatise of beauty or the Questions on the origin and nature of belo 1752 and some of its developments in the salons of 1763, 1765 and 1767 (and in the essays on the painting that complete the salons 1765). Some writings by Denis Diderot on the beautiful and the arts

\footnotetext{
Abstract The intention of this article is to clarify some aspects of philosopher Denis Diderot's aesthetic reflection, tying to connect both his works The Treaty of Beauty with a selection of passages from his Reports of the Salons. The Treaty was edited as an entry about beauty in the Encyclopédie in 1752. It is a treaty both in the doctrinal style employed, as it also is due to the epistemological method that seeks to find in the origins the true nature of beauty. The reports on the Salons and the Essays on Painting of 1765 are considered Diderot's most important writings about art. In them, the philosopher applies and questions his theories in the practice of the critique of art. Keywords: Diderot, history of arts, criticism.
} 
Este trabalho procura contribuir ao esclarecimento do pensamento estético de Denis Diderot e do seu gosto no que diz respeito à arte da pintura. Nessa perspectiva, buscaremos correspondências entre O Tratado do Belo, os relatórios dos Salons, de 1763, 1765 e 1767 e os Ensaios sobre a pintura que completam o Salon de 1765.

O Tratado do Belo ou Indagações sobre a origem e a natureza do Belo é um texto do gênero do tratado que busca esclarecer o conceito do Belo de uma maneira epistemológica, analisando e criticando as mais importantes variações do conceito de Belo ao longo da história da filosofia apresentando seus movimentos e suas variações. Curto em relação a o que se espera de um tratado, o texto, adaptável ao formato de verbete é editado como tal em 1752 no volume II da Encyclopédie. Como verbete, da Encyclopédie, esse artigo de Diderot participa dessa ferramenta essencial do projeto des Lumières de democratizar o conhecimento e a filosofia na construção de uma humanidade que, "mais instruída, será mais virtuosa e será mais feliz" ${ }^{1}$. Nesse texto Denis Diderot expõe a sua Teoria da percepção das relações, que situa o sentimento do Belo na sensação de prazer e de agrado que ocorra na percepção das relações que temos com os objetos, "Quando há belo". Para determinar as qualidades e os efeitos do Belo, Diderot encontra no momento da percepção a origem do prazer estético. Um agrado tudo subjetivo que nasce no ato de percepção das relações cognitivas (sensíveis e intelectuais) que encontramos nas artes, construindo nossa cultura e nosso gosto ${ }^{2}$. O Tratado do Belo discute e propõe conceitos para esclarecer o Belo. Os relatórios dos Salons se apresentam nesse trabalho como o relatório da experiência do belo (e do feio) e a aplicação dos conceitos discutidos no Tratado do Belo por Diderot.

Convidado pelo filosofo Melchior Grimm para assumir os relatórios dos Salons para a "Correspondance littéraire, critique et philosophique", periódico, escrito à mão e em francês é lido por uma grande parte das monarquias europeias ditas "illuminées".

Os relatórios dos Salons ocupam Diderot entre 1759 e 1781, o gênero é aquele da correspondência que, proporcionando um ambiente de intimidade entre os dois filósofos, age com garantia de sinceridade e de liberdade de expressão.

Diderot, o filósofo "touche à tout", que sempre navegou entre os gêneros literários, vai inventar um novo: a crítica de arte para descrever, analisar e refletir e partilhar as

${ }^{*}$ Frédéric René Guy Petitdemange é Historiador de Arte e Arqueologia, Professor da Escola de Comunicação e Arte da Universidade de São Paulo (ECA USP), ORCID $<$ https://orcid.org/0000-00020773-3851> experiências estéticas que ocorrem nos Salons.

Destacamos três gêneros literários escolhidos por Diderot para discutir o Belo, as artes e o gosto: o tratado, adaptado em verbete, o ensaio e a crítica de arte. Como gênero inventado, a crítica de arte de Diderot procede da diversificação dos discursos 
1 Denis DIDEROT e D'ALEMBERT: Discurso preliminar à Encyclopédie. 1751, acessível em <http://editoraunesp.com. $\mathrm{br} / \mathrm{blog} /$ editora-unesp-lancaa-enciclopedia-de-diderot-ed\%E2\% 80\% 99alembert-emcinco-volumes>

20 termo "gosto" é empregado aqui no seu sentido figurado ativo a partir do séc. XVI na língua francesa: "Faculdade de discernir as qualidades e os defeitos numa obra artística ou intelectual". Dictionnaire historique de la langue française. Le Robert. Paris 2000.

3 DIDEROT, Denis: Essais sur la peinture 1765. Collection savoir : sur l'art. Editions Hermann. Editeurs des sciences et des arts. DIDEROT, Denis: Les pensées détachées sur la peinture 1774. In Oeuvres complètes. Garnier Frères Editeurs Paris 1876

4Denis DIDEROT e D'ALEMBERT: Discurso preliminar a Encyclopédie. op. Cit.

$5<$ www.lib.uchicago.edu/efts/ ARTFL/projects/encyc/groult/ images/learning_large.jpg >. Reconstitução sob a forma de uma tabela do texto de Bacon The Advancement of Learning (1605, Livre II) reprise dans De Dignitate et Augmentis scientiarum (1623) da edição de William Aldis Wright (Oxford, Clarendon Press, 1868 e 1926).

$6<$ www.lib.uchicago.edu/efts/ ARTFL/projects/encyc/groult/ images/knowledge_large.jpg>. Cyclopaedia d'Ephraïm Chambers (2 volumes : ed. 1728 e1742 à Dublin). filosóficos que ocorre no século XVIII. Maneira para alcançar leitores da elite europeia avida de informações sobre os eventos culturais da Paris do século XVIII, mas também maneira de adaptar o gênero de discurso a o tema discutido. Na obra de Diderot, cada gênero de discurso propõe uma abordagem diferente do Belo, das artes e do gosto. Dos conceitos do belo expostos e discutidos no Tratado do Belo à experiência in situ narrada nos textos críticos dos Salons passando pelos Ensaios ${ }^{3}$ que discutem os preceitos artísticos pós-experiência estética, cada ângulo de visão contribua a esclarecer a questão do belo e das artes.

Para Diderot, os relatórios dos Salons são textos críticos das Belas Artes que situam o filosofo no lugar do espectador que descobre, observe, descreve, analisa e julga as obras do Salon. Mesmo se reservados inicialmente a uma elite, os relatórios dos Salons participam do esforço iluminista em expandir e democratizar o conhecimento diversificando os meios da sua difusão.

O belo e as artes são temas essenciais no projeto lluminista, e constitua um tema fundamental da Encyclopédie que almeja organizar e descrever as artes, as ciências e os ofícios no século XVIII.

"A obra que nos estamos começando (e que desejamos terminar) tem dois objetos: Como enciclopédia, ela deve expor, o quanto for possível, a ordem e o encadeamento dos conhecimentos humanos; como dicionário raciocinado das ciências, das artes e dos oficios, ela deve conter, sobre cada ciência e sobre cada arte, que seja liberal ou que seja mecânica, os princípios gerais que constituem a sua base e os detalhes os mais essenciais que faz o corpo e a substância dela." 4

\section{O Tratado do Belo e a situação da arte da pintura na organiza- ção dos conhecimentos humanos da Encyclopédie}

Na sua organização, o projeto iluminista da Encyclopédie difere das precedentes organizações do entendimento humano de Bacon $^{5}$ e dos conhecimentos humanos de Chambers $^{6}$.

No Discours préliminaire da Encyclopédie de 1751 d’Alembert apresenta o Sistema figurado dos conhecimentos humanos (Système figure des connaissances humaines).

Nessa organização figurada de 1751 dos conhecimentos (Ciências e artes), as artes da música, da pintura, da escultura, da arquitetura civil e da gravura pertencem à categoria da "imaginação". Essa nova classificação remete a classificação da "poesia", já distinguida por Bacon (historia (memoria), poesia (imaginação), filosofia (Razão)), com três subclassificações: narrativa, representativa e alusiva, a pintura podendo ser relacionada às três categorias. Diferente também da organização de Chambers que situa a arte da pintura nas artes óticas (visuais), no conjunto das artes ditas liberais, a Encyclopédie desloca a pintura do domínio da razão para aquele do sentimento.

Essa valorização da imaginação indica uma variação notável na concepção enciclopedista, ela não afasta mais da verdade, como pensava Descartes e não é mais uma das principais fontes de erro como ponderava Malebranche. No "Système figuré des connaissances" de 1751, ela é uma faculdade de conhecimento como a memoria e a razão. 
$R A I S O N$

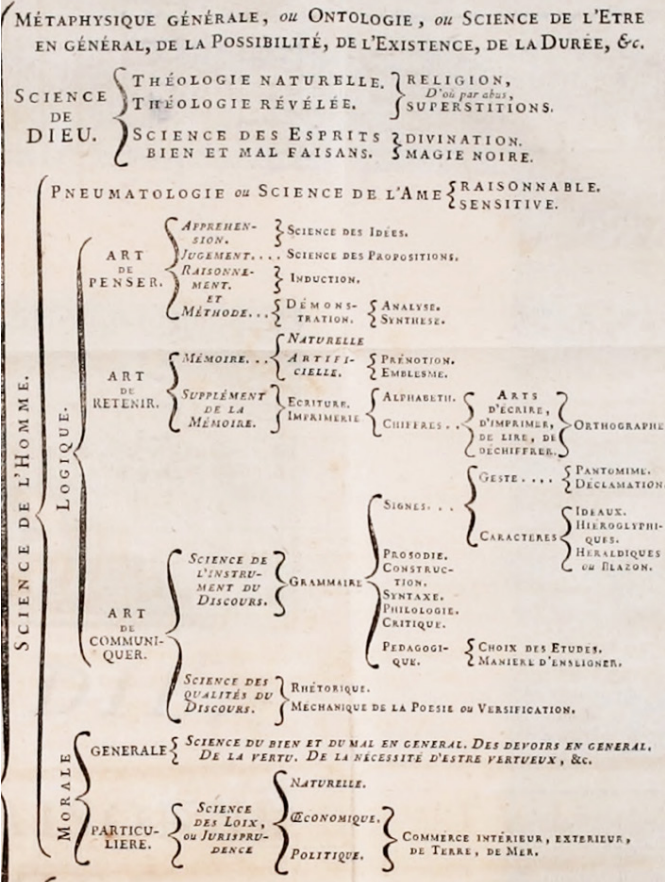

I MAGINATION.

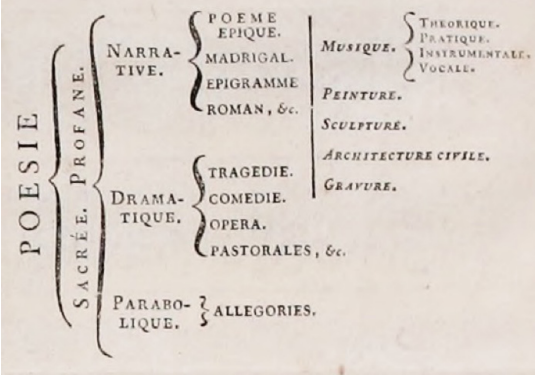

Figura 1: Sistema figurado dos conhecimentos humanos. Versão de 1751. Fonte: <https://encyclopedie.uchicago.edu/content/ système-figuré-des-connaissances-humaines-de-lencylcopédie>, disponível em 14-junho-2021.

7 IMAGINATION, IMAGINER, (Página 8:560) Verbete da Encyclopédie acessível no site $<$ portail.atilf.fr/encyclopedie/>.

8"RAZÃO: $1^{\circ}$. Pode se entender simplesmente e sem restrição essa faculdade cuja Deus doteu os homens, para conhecer a verdade. Qualquer luz que ela segue, e á qualquer ordem de matérias que ela se aplica." (...) Verbete da Encyclopédie. Op.cit.
A definição de Voltaire para a Encyclopédie esclarece essa alteração:

"Imaginação, imaginar (logica, metafisica, literatura e belas artes). É o poder que cada ser sensivel experimenta em si de representar-se no seu espírito as coisas sensiveis; essa faculdade depende da memoria. Veem-se homens, animais, jardins; essas percepções entrem pelos sentidos, a memória os retém, a imaginação os compõe. É por isso que os antigos Gregos chamaram as musas filhas da memoria.

É muito essencial notar que essas faculdades de receber ideias, de retê-las, de compô-las, são do nível das coisas cujas não podemos dar nenhuma razão; essas competências invisíveis de nosso ser estão na mão de Ser supremo que nos fez e não na nossa. Talvez esse dom de Deus, a imaginação, é ou único instrumento com o qual compomos ideias e mesmo das mais metafisicas." 7

Para os enciclopedistas, a imaginação é assunto de conhecimento que concerne as áreas da "logica, da metafisica, da literatura e das belas artes". A imaginação, como a razão ${ }^{8}$ é uma faculdade que depende da "memoria", são todas dons de Deus, todas são faculdades de conhecimento inexplicáveis pela razão.

A imaginação e a razão divergem nas suas finalidades e nos seus objetivos em relação às sensações arquivadas pela memoria. A razão busca a verdade sobre as sensações e a imaginação compõe com as lembranças das sensações para, entre outras produções, produzir o Belo. Nessa perspectiva enciclopedista, a busca do Belo é de uma veemência da mesma ordem que as buscas do Bem, do Justo, e do Verdadeiro. O tema interessa, o seu entendimento é difícil como o avisa que Diderot na abertura do Tratado do Belo. 
9 DIDEROT Denis: Verbete do Belo da Encyclopédie. Op.cit.

10 O termo "Beaux-arts" aparece na língua francesa por volta de 1640 nas discussões sobre as criações de academias. Como termo classificador nas artes, é empregado no início nos dois gêneros, no feminino, em Bossuet (1658), na forma "belles arts" emprestado à forma italiana de "Bellas artes". Entretanto, a forma masculina "beaux-arts" prevalece como adaptação francesa e significa no meio do século XVIII, "as técnicas da beleza". Assim, a expressão "beaux-arts" propõe uma nova categoria de "arte"(técnica/ prática) destacando-se das expressões "artes mecânicas" e "artes liberais". A cisão aconteça nas "artes liberais", provocada nos meios acadêmicos por uma variação de valor defendendo a necessidade de uma nova categoria de arte para valorizar as técnicas nobres, com a arte da poesia, a arte da pintura, a arte da música, bem como a arte militar e a arte naval.

11 DIDEROT Denis: Verbete do Belo da Encyclopédie.Op.cit.

12 SENTIMENTO ÍNTIMO: (metafisica) $\mathrm{O}$ sentimento intime que cada um de nós tem da sua própria existência, e do que ele experimenta em ele-mesmo, é a primeira fonte e o primeiro princípio de qualquer verdade da qual somos susceptíveis. Não há nenhuma que seja mais imediato para nos convencer que o objeto de nosso pensamento existe 0 quanto realmente que nosso pensamento mesmo, pois esse objeto e nosso pensamento, e o sentimento íntimo que nós temos dele não realmente que nos mesmos que pensamos, que existe e que temos o sentimento disso. Tudo que se queria dizer para comprovar esse ponto ou para esclarecê-lo mais, só o faria se obscurecer: do mesmo modo se se quisesse achar algumas coisas de mais claro do que a luz, e ir além, só se acharia as trevas. (...) O artigo é de Diderot.Verbete da Encyclopédie. Op.cit.
"Tudo mundo raciocina sobre o belo: a gente o admira nas obras da natureza, a gente o exige nas produções das artes: a gente acorda ou recusa essa qualidade a qualquer momento; entretanto, si a gente pergunta aos homens do gosto o mais seguro e o mais delicado, qual é a sua origem, a sua natureza, a sua noção precisa, a sua verdadeira ideia, a sua exata definição, se é uma coisa de absoluto ou de relativo, se há um belo essencial, eterno, imudável, regra e modelo do belo subalterno, ou se a beleza é como as modas: vemos imediatamente os sentimentos partilhados; uns confessam a sua ignorância, outros se jogam no ceticismo. Como é que quase todos os homens sejam de acordo que tivesse um belo, que tivesse tantos entre eles que o sintam: vivamente onde ele está, e que tão pouco saiba o que é?" 9

"Exigido nas produções das artes", o Belo é produto das articulações, ou das composições (para parafrasear Voltaire) feitas pela imaginação. Segundo a Encyclopédie, a imaginação se articula nas práticas das Belas artes que são as artes da música, pintura, escultura, arquitetura civil e gravura. Se a expressão "Belas artes" (Beaux $\left.\operatorname{arts}^{10}\right)$, que reúne as noções de Belo e de artes classifica literalmente as artes que produzem o belo indicado o objetivo dessas práticas artísticas, ele remete também ao gosto italiano pela sua etimologia e caracteriza a importância do modelo italiano na concepção iluminista das artes.

Nesse esforço dos enciclopedistas de esclarecimento da palavra arte, a classificação "Belas artes" considera que, nas artes, há práticas que obram especificamente na produção do Belo, sentimento subjetivo e infinito cuja percepção não se faz no domínio da razão, como avisa Diderot no Tratado do Belo.

"O belo não é sempre a obra de uma causa inteligível. ${ }^{11}$ (...) »

A questão do sentimento é essencial na reflexão do filosofo, no verbete da Encyclopédie "sentimento íntimo"12 ele precisa o caractere primordial e subjetivo da nossa experimentação e percepção do mundo.

(...) "É a indeterminação dessas relações, a facilidade de apreendê-las e o prazer que acompanha sua percepção que fez imaginar que o belo era mais uma questão de sentimento do que de razão. Ouso afirmar que todas as vezes que um princípio nos for conhecido desde a mais tenra infância, e que fizermos, por hábito, uma aplicação fácil e súbita dele aos objetos situados fora de nós, acreditaremos que o julgamos por sentimento. Mas seremos obrigados a confessar nosso erro em todas as ocasióes nas quais a complexidade das relações e a novidade do objeto suspenderiam a aplicação do princípio. Então, o prazer esperará, para ser sentido, que o entendimento tenha pronunciado que o objeto é belo. Aliás, o julgamento em tal caso é quase sempre sobre o belo relativo, e não sobre o belo real. "(...)

A teoria de Diderot situa as origens do sentimento do belo no prazer ressentido na percepção das relações que o espectador estabelece com os objetos e com as obras e arte.

Essa ideia de prazer sentido na percepção de relações já tinha sida apresentada por Diderot em "Memoires sobre diferentes assuntos de matemáticas" em 1748. 
13 Denis DIDEROT: Mémoires sur différents sujets de mathématiques. Publicado em 1748 em Paris por Durand et Pissot.

14 DIDEROT Denis: Verbete do Belo da Encyclopédie. Op. Cit.

15 Idem.

16 "Beleza terme relativo, é a potência ou faculdade de excitar em nós a percepção das relações agraveis. Diz agradáveis, para me conformar a acepção geral e comuna do termo beleza: mas acredito que, filosoficamente falando, tudo que possa excitar em nós a percepção de relações, é belo." DIDEROT Denis: Verbete do termo Beleza ( beauté) da Encyclopédie. Op. Cit.

17 “O prazer é um sentimento de alma que nos torna felizes pelo menos durante todo o tempo em que dele usufruímos. Nunca é demais admirar o cuidado que a natureza tem de nos cumular de prazeres." Verbete do prazer da Encyclopédie.Op.cit.
"O prazer em geral consiste na percepção das relações. Esse príncipe acontece na poesia, na pintura, na arquitetura, na moral, em todas as artes e em todas as ciências. Uma bela máquina, um belo quadro, um belo pórtico, só nos agradam pelas relações que podemos notar neles. [...] $\rrbracket^{13}$

Diderot enfatiza que se esse príncipe pode ser aplicado a todas as produções humanas ele também se abra sobre a questão muito mais ampla do gosto.

"Esse príncipe deve servir de base por um ensaio filosófico sobre o gosto se se encontrasse alguém suficientemente instruído para fazer disso uma aplicação geral a tudo que ele abraça "(...)» ${ }^{14}$.

Para situar os lugares do Belo, Diderot começa por citar as belas artes e a moral, mantendo o antigo preceito grego que associa os sentimentos do Belo e do Bem, lugares corriqueiros do agrado. Em seguida, ele expande o princípio a todas as artes e todas as ciências e corrobora essa ideia enumerando objetos diversos que recebem o adjetivo "belo" no uso corrente da língua. Separando as artes e as ciências, Diderot distingue a emoção e razão no desperto da percepção das relações e no sentimento do Belo.

Quatro anos depois, no verbete da palavra "Belo", o filosofo tem a matéria para desenvolver a sua teoria das percepções, evidenciando o aspecto fundamental da percepção das relações nas sensações de admiração e de prazer.

\section{"A percepção das relações é o único fundamento da nossa admiração e dos nossos prazeres. [...] $»^{15}$}

No verbete "admiração" da Encyclopédie, Diderot situa as origens da admiração na perfeição. A qualidade da perfeição estabelece sua permanência no tempo (na memoria). Na frase seguinte, Diderot chama o Belo para determinar as qualidades da admiração. Assim, os termos "admiração" e "perfeição" se determinam em relação ao efeito do belo que são susceptíveis de despertar no espectador. Diderot define a beleza ${ }^{16}$ na Encyclopédie, não com efeito do belo, mas com a faculdade ou a potência de despertar em nos sensações agradáveis.

"Admiração (Moral) é o sentimento produzido em nós pela presença de um objeto qualquer, intelectual ou físico, ao qual atribuímos alguma perfeição. Se o objeto for verdadeiramente belo, a admiração perdura. Se a beleza for apenas aparente, a admiração desaparece, através da reflexão. Se o objeto for tal que, quanto mais o examinarmos, mais perfeições descobrimos nele, a admiração aumenta. Só admiramos muito o que está acima de nossas forças ou conhecimentos. Assim, a admiração ora é filha de nossa ignorância, ora de nossa incapacidade: tais princípios são tão verdadeiros que o que é admirável para um pode nem mesmo chamar a atenção de outro. É preciso não confundir surpresa com admiração: uma coisa feia ou bela, desde que não seja ordinária em seu gênero, causa-nos surpresa; mas só as belas têm o dom de produzir em nós a surpresa e a admiração."

O agrado e o prazer ${ }^{17}$ são sentimentos essenciais na busca das origens e da natureza do belo na relação que eles estabelecem com o estado de felicidade. 
18 «Nada é mais incontestável do que a existência de nossas sensações, e, sendo assim, para provar que elas são o princípio de todos os nossos conhecimentos, basta demonstrar que podem sê-lo; pois em boa Filosofia, toda dedução que tem por base fatos ou verdades reconhecidas é preferível a outra, apoiada apenas em hipóteses, por engenhosas que sejam. Por que supor que temos de antemão noções puramente intelectuais se, para formá- las basta refletir sobre nossas sensações? A explicação que ofereceremos aqui mostrará que essas noções, de fato, não têm outra origem. " Encyclopedie, discurso preliminar. Op.cit.

19 Verbete do Belo da Encyclopédie. Op.cit.

20 Idem.
Na última parte do Tratado do Belo à teoria da percepção e seu desenvolvimento no, a ideia do belo do Diderot, como em Aristóteles e em São Toma de Aquino, se desperta na relação com o mundo fora de mim perceptível pelos sentidos ${ }^{18}$.

"Chamo então belo fora de mim tudo que contêm em si algo que desperta no meu entendimento a ideia de relações; e belo em relação a mim, tudo que desperta essa ideia.» $^{19}$

O ato de percepção é uma relação e evidencia outras relações entre o espectador e os objetos. Diderot descreve essa operação antes de definir o que ele entende com a palavra "relação".

"Quando digo tudo o que contém em si do que despertar em meu entendimento a ideia de relações, ou tudo o que desperta em mim essa ideia, é porque se deve distinguir bem as formas que estão nos objetos e a noção que tenho deles. Meu entendimento não põe nada nas coisas e não tira nada delas. Que eu pense ou não nas fachadas do Louvre, todas as partes que a compõem não deixam de ter tal ou qual forma e tal ou qual arranjo entre si. " (...) ${ }^{20}$

O filosofo esclarece o que ele entende com a palavra "relações"

(...) "Mas, perguntar-me-ão: o que entendeis por relações"? Dar o nome de belo a algo que nunca foi considerado como tal não significa mudar a acepção dos termos? Parece que, em nossa língua, a ideia desse belo está sempre junto à de grandeza e que colocar a diferença específica numa qualidade que convém a uma infinidade de seres que não têm grandeza nem sublimidade não é definir o belo. O Sr. Crouzas falhou, sem dúvida, quando sobrecarregou sua definição do belo com um número tão grande de características que ela ficou restrita a um pequeno número de seres. Mas não é cair num defeito contrário torná-la tão geral que ela pareça abarcar todos, sem excetuar um monte de pedras informes, lançadas ao acaso nas margens de uma pedreira? Todos os objetos acrescentar-se-á, são suscetíveis de relações entre si, entre suas partes e com outros seres; não existem aqueles que não possam ser arranjados, ordenados, simetrizados. A perfeição é uma qualidade que pode convir a todos, mas o mesmo não acontece com a beleza. Ela só pertence a um pequeno número de objetos. Eis, parece-me, se não a única, pelo menos a mais forte objeção que mepossa ser feita, e vou tentar responder a ela." (...)

Explorando as expressões da língua corrente que empregam o adjetivo "belo", Diderot aponta a o desacerto do questionamento do Belo em vigor que limita o discernimento a ideia genérica de "grandeza" ou a qualidade imprecisa de "perfeição", que não bastam para discernir e precisar as especificidades subjetivas do sentimento Belo. Para remediar essa falta, o filosofo indica outro lugar para esclarecer as origens e a natureza do Belo. A sua teoria da percepção das relações desloca o lugar do Belo das sensações agradáveis dos objetos para o prazer da percepção de relações que se estabelecem entre o desconhecido, o conhecido e o reconhecido. A relação é momento do "conhecendo" de percepções possíveis, subjetivas e liberta o julgamento do belo das categorias de valores preestabelecidas. 
"A relação, em geral, é uma operação do entendimento, que considera seja um ser, seja uma qualidade, enquanto esse ser ou qualidade supóem a existência de um outro ser ou outra qualidade. Exemplo: quando digo que Pierre é bom pai, considero nele uma qualidade que supóe a existência de um outro, a de seu filho, e assim, do mesmo modo, as outras relações, quaisquer que possam ser. De onde se segue que, embora a relação só esteja em nosso entendimento, quanto à percepção, ela não deixa de ter seu fundamento nas coisas. Direi que uma coisa contém em si relações reais todas as vezes que for revestida de qualidades que um ser constituído de corpo e espírito como eu não poderia considerar sem supor a existência de outros seres ou de outras qualidades, seja na própria coisa, seja fora dela. E distribuirei as relações em reais e percebidas. Mas há uma terceira espécie de relações; são as intelectuais ou fictícias, as que o entendimento humano parece colocar nas coisas. Um estatuário olha um bloco de mármore; sua imaginação, mais rápida quanto seu cinzel, elimina do mármore todas as partes supérfluas e discerne no bloco uma figura. Mas essa figura é imaginária e fictícia. Ele poderia fazer, sobre uma porção de espaço determinado por linhas intelectuais, o que acaba de executar por imaginação num bloco informe de mármore. Um filósofo olha para um monte de pedras lançadas ao acaso; ele aniquila pelo pensamento todas as partes desse monte que produzem irregularidades e consegue fazer sair dali um globo, um cubo, uma figura regular. O que isso significa? Que, embora a mão do artista só possa traçar um desenho sobre superfícies resistentes, ele pode pelo pensamento transportar sua imagem sobre todo o corpo no espaço e no vazio; que digo eu? Sobre todo o corpo? A imagem, transportada pelo pensamento nos ares, ou extraída pela imaginação dos corpos mais informes, pode ser bela ou feia; mas não a tela ideal à qual ela foi ligada, ou o corpo informe da qual a fizemos sair." (...)

(...) "Quando digo, pois, que um ser é belo pelas relações que se observam nele, não falo de modo algum de relações intelectuais ou fictícias que nossa imaginação transporta para ele, mas de relações reais, que estão nele e que nosso entendimento observa com o auxílio dos sentidos. Em contrapartida, sustento que, quaisquer que sejam essas relações, são elas que constituirão a beleza, não no sentido estrito em que o bonito é oposto ao belo, mas num sentido, ouso dizer, mais filosófico e mais conforme à noção do belo em geral e à natureza das línguas e das coisas. " (...)

O prazer na percepção das relações encontra a sua origem, produz o seu efeito e estimula o pleno exercício das nossas faculdades de sentir, pensar, memorizar e compor. Essas percepções de relações não poderiam existir se o homem não tivesse um receptor dotado de qualidades apropriadas para sentir em primeiro lugar

(...) "Nascemos com as faculdades de sentir e de pensar. O primeiro passo da faculdade de pensar é examinar suas percepções, reuni-las, compará-las, combiná-las, perceber entre elas relações de conveniência e inconveniência etc. Nascemos com necessidades que nos obrigam a recorrer a diferentes expedientes, dentre os quais nos convencemos de que há os bons, maus, rápidos, curtos, completos, incompletos etc., seja pelo efeito que esperamos deles, seja pelos que eles produzem. A maior parte desses expedientes é uma ferramenta, uma máquina, ou alguma invenção desse gênero. Mas toda máquina supõe combinação, arranjo de partes que tendem a um mesmo fim etc. Eis nossas necessidades e o exercício mais imediato de nossas 
21 Idem.

22 DIDEROT Denis: Verbete do Belo da Encyclopédie. Op.cit.

23 BOILEAU DESPREAUX Nicolas: Épître IX verso 43. Edição Larousse. Paris 1949. faculdades, Que concorrem tão logo nascemos para nos dar as ideias de ordem, arranjo, simetria, mecanismo, proporção, unidade. Todas essas ideias vêm dos sentidos e são factícias. Passamos da noção de uma multidão de seres artificiais e naturais, arranjados, proporcionados, combinados, simétricos, para a noção positiva e abstrata de ordem, arranjo, proporção, combinação, relações, simetria, e à noção abstrata e negativa de desproporção, desordem e caos. " (...) 21

(...)" não importa o que se diga sobre todas as causas da diversidade dos julgamentos, não há razão para pensar que o belo real, que consiste na percepção das relações, seja uma quimera. A aplicação desse princípio pode variar ao infinito, e suas modificações acidentais podem produzir dissertações e guerras literárias, mas nem por isso o princípio é menos constante. Talvez não haja dois homens sobre toda a terra que percebam exatamente as mesmas relações nos mesmos objetos e que o julguem belo no mesmo grau. Mas se houvesse um só que não fosse afetado por relações em algum gênero, e se ele fosse insensível somente em alguns gêneros, esse fenômeno denunciaria nele um defeito de economia animal e estaríamos sempre afastados do ceticismo, pela condição geral do resto da espécie." (...)

O mundo é primeiramente uma experiência sensível. Há belo num objeto quando ele desperta um conjunto de relação com o sentimento intime do espectador no processo de percepção e de entendimento do mundo.

\section{O elogio de Diderot nos relatórios do Salons}

\section{Jean Baptiste Simeon Chardin}

"Conforme a natureza de um ser, conforme que existe em nós a percepção de um número maior de relações e conforme a natureza das relações que ele excita, é bonito, é belo, mais belo, muito belo ou feio; baixo, pequeno, grande, elevado, sublime, ultrajado, burlesco ou prazeroso; e seria fazer uma obra muito grande e não um artigo de dicionário que de entrar em todos os detalhes, é suficiente mostrar os princípios, deixamos ao leitor o cuidado das consequências e das aplicações. Mas podemos Ihe assegurar, que seja que ele escolhe os seus exemplos na natureza, ou que ele os pede emprestados da pintura, da moral, da arquitetura, da musica, ele encontrara sempre que ele da o nome de belo à tudo que contem em si alguma coisa que possa despertar a ideia de relações; e o nome de belo relativo, a tudo que desperta relações convenientes com as coisas das quais precisamos fazer a comparação. "22

«Rien n'est beau que le vrai. Le vrai seul est aimable. $»^{23}$

Diderot destaca a importância da conveniência no desperto das relações.

"CONVENIENNCIA: Em pintura, significa não somente o acordo das partes para formar um tudo que não seja ridículo, mas a sabedoria e o gosto na escolha dessas partes tomadas relativamente ou separadamente. É a conveniência que assina cada objeto de um quadro o caractere que Ihe convém em relação a sua grandeza, sua disposição, sua forma, sua riqueza ou a sua simplicidade. É por ela que não se aloja um rei numa casa de burguês, e um carvoeiro num palácio. É ela que ensina a não 
24DOM PERNETY : Dictionnaire portatif de peinture, sculpture et gravure. Paris, 1757. Librairie Bauche.

25 "NATUREZA (poesia): Natureza em poesia é: 1 . Tudo que é atualmente existente no universo; 2. Tudo que existiu antes de nós e que nós podemos conhecer com a história dos tempos, dos lugares e dos homens; 3 . Tudo que possa existir, mas que talvez nunca tenha existido e que jamais existira. Nós entendemos na História a fábula e todas as invenções poéticas as quais concede-se uma existência de suposição que vale nas artes tanto quanto a realidade histórica. Assim, há três mundos aonde o gênio poético pode ir escolher e tomar o que lhe convém para formar as suas composições: 0 mundo real, o mundo histórico, que compreende o fabuloso, e o mundo possível; e esses três mundos chama-se de natureza. (...)" O Verbete é de Jaucourt - Verbete da Natureza da Encyclopédie. Op.cit.

26 DIDEROT Denis: Oeuvres Complètes. Tome X. Ed. Garnier Frères Paris 1876.. Salon de 1763. Salon de 1765 Salon de 1767. Les Essais sur la peinture 1765.

27 DIDEROT Denis: Oeuvres Complètes. Salons de 1763. Op.cit vestir uma caipira de estofa de lençóis de ouro ou de seda, de não pôr a cabeça de um jovem sobre o corpo de um velho, nem a mão de uma mulher na extremidade de um braço de homem, a conservar cada objeto suas proporções naturais seguindo (ou segundo) a perspectiva, a dar a cada figura o caractere que lhe convém, segundo a paixão natural que o move, segundo sua idade, seu sexo e sua condição; a manter o costume tanto para as fábricas, os vestuários, as armas, etc. , que para a maneira de agir, enfim, a dispor tudo de maneira que o conjunto fizesse um tudo em acordo, a não introduzir nada nas composições que não tivessem verossimilhança, que não seja enérgico, natural, e conforme as regras do bom gosto e da (bienséance). Decência. A maior parte dos pintores ignora tudo, ou não faz bastante caso dessas leis de conveniência, seja nas atitudes, seja enfim na disposição dos objetos para a ordenança dos seus quadros. Alguns as olham como minúcias, enquanto as pessoas conhecedoras e de bom senso as tratam como erros reais, porque eles sabem de quais consequências fazem as conveniências essenciais, sobretudo numa arte que tem por objeto de fazer ilusão, de agradar e de instruir, e que não deve consequentemente expor nada aos olhos que não seja uma imitação exata da bela natureza. $A$ decência não é exatamente a mesma coisa que a conveniência, não se pode assim confundi-las." 24

Para Diderot a "conveniência" é a qualidade do Belo perceptível imediatamente pelo espectador na comparação (confrontação) da pintura e do seu modelo natureza ${ }^{25}$. A conveniência, como primeira relação entre o espectador e a obra deve produzir um efeito de verdade. Para isso, ela é o resultado de um sábio acordo entre as partes e revela o gosto do pintor na escolha dos objetos da natureza e na sua maneira de representa e dispô-los na tela. Além da verossimilhança dos objetos representados, a conveniência concerne também os ares e as posas dos personagens e se articula com as noções de decência e de decoro. Para esclarecer essa relação específica de verdade Diderot propõe a expressão "verdade de natureza" (vérité de nature) e com ela descreve os efeitos verificáveis na confrontação da pintura com o objeto. Para essa qualidade do belo, os elogios são para Jean Simeon Chardin e sua maneira singular de pintar que parece não corresponder ao gosto do seu tempo.

"É sempre a natureza e a verdade. Você pegaria as garrafas pelo gole se você tinha sede, os pêssegos e as uvas despertam o apetite e chamam a mão. Mr.Chardin é homem de espirito, ele entende a teoria da sua arte, ele pinta de uma maneira que Ihe é própria e seus quadros serão procurados um dia."

Os termos "verdade" e "natureza" se articulam e se justificam um ao outro. Inseparáveis, é junto que eles qualificam e autentificam a conveniência, o decoro e a decência e os seus efeitos. Os elogios continuam no Salon de 1763.

"Há no Salon vários pequenos quadros de Chardin, eles representam quase todos, frutas com acessórios de uma refeição. É a natureza mesma; os objetos estão fora da tela e de uma verdade de enganar os olhos" 26

"Chardin é tão verdadeiro, tão verdadeiro, tão harmonioso, que mesmo só se veja na tela a natureza inanimada, vasos, garrafas, pão, vinho, uvas, frutas, patês, ele se sustenta e talvez Ihe tira de dois dos mais belos Vernet, do lado do qual ele não hesitou de se colocar. "(...) 27 


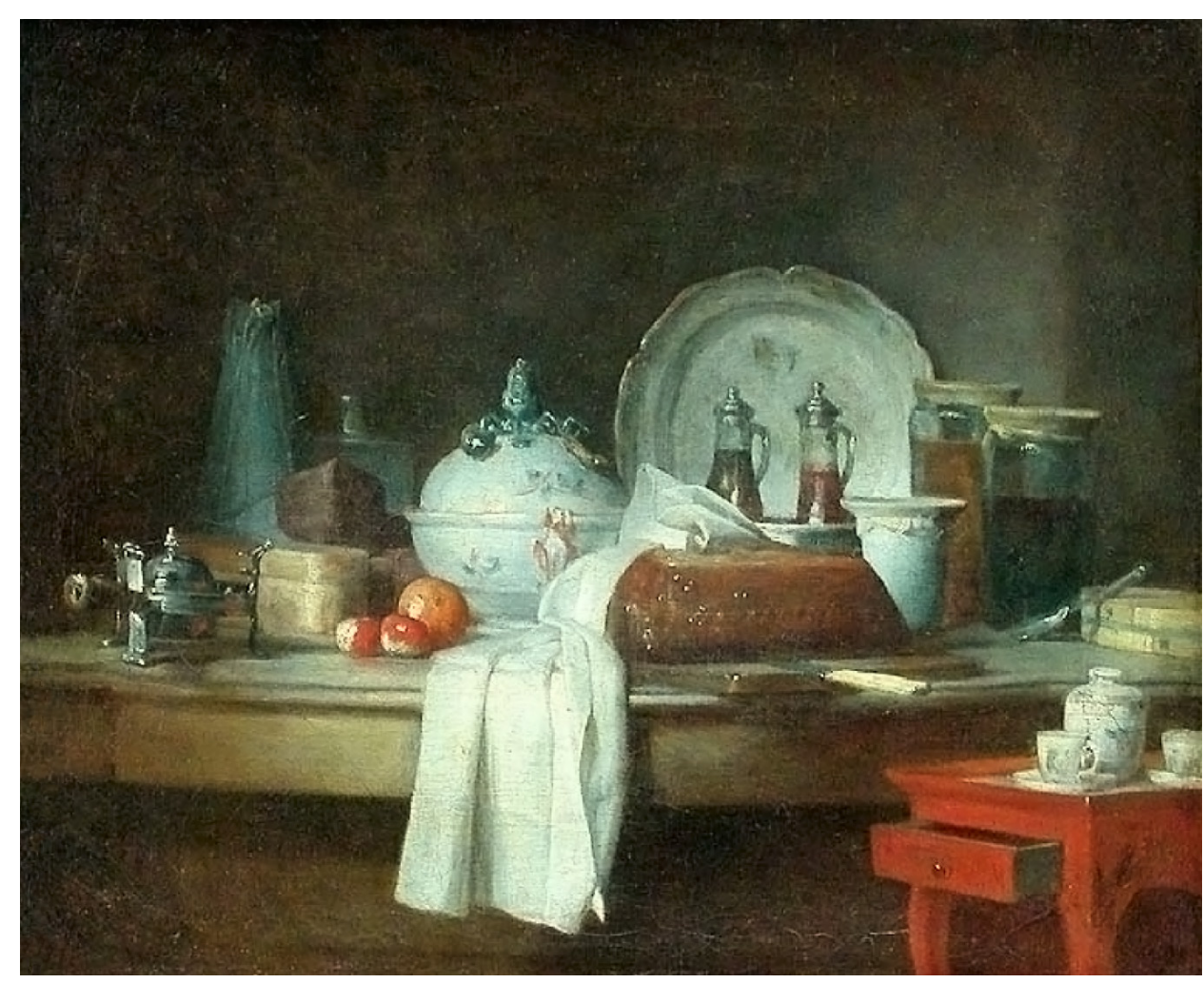

Figura 2: Jean Baptiste Simeon, La table d'office, dit aussi Les débris d'un déjeuner, 1763 ? óleo sobre tela. $38 \mathrm{~cm} \times 46 \mathrm{~cm}$ Museu do Louvre. Fonte: <collections.louvre. fr/ark:/53355/ cl010065934>, disponível em 14 de junho de 2021.

28 DIDEROT Denis:_Oeuvres Complètes. Salons de 1763. Op. cit.

29 "Ah meu amigo, cuspe na cortina de Apeles e sobre as uvas de Zeuxis. Engana-se sem dificuldade um artista impaciente e os animais são maus juízos em pintura." Denis DIDEROT Salon de 1763. Op. cit.

30 DIDEROT Denis: Oeuvres Complètes. Salons de 1763, 1765 e 1767, Les essais sur la peinture. Op. cit.
"É esse que é um pintor, é esse que é um colorista." 28

Nos Salon de 1765, Diderot compara Chardin a Apeles e a Zeuxis ${ }^{29}$ e Vernet e torná-lo um pintor herói, exaltando o Belo da pintura de gênero, o filósofo critica a hierarquia dos gêneros e os critérios estéticos do julgamento predeterminados pelos "habitos" que operam na construção do grande gosto. Essa ideia desenvolvida nos Ensaios sobre a pintura com esses termos.

"Os pintores de gênero e os pintores de história não confessam nitidamente o menosprezo que se dedicam reciprocamente; mas a gente o adivinha. Estes últimos encaram os primeiros como cabeças estreitas, sem idéias, sem poesia, sem grandeza, sem elevação, sem gênio, que vão se arrastar servilmente atrás da natureza, que não ousam perder de vista um momento. Pobres copistas, que eles comparariam de bom grado ao nosso artesão dos Gobelins, (...)(atelier real de tapeçaria em Paris) o pintor de gênero, por seu lado, encara a pintura histórica como um gênero romanesco, em que não há nem verossimilhança, nem verdade, onde tudo é desmedido, que nada tem de comum com a natureza, onde a falsidade se revela, quer nos caracteres exagerados, que não existiriam em parte alguma, quer nos incidentes, que são todos de imaginação, quer no tema inteiro, que o artista jamais viu fora de sua cabeça vazia, quer nos detalhes, que ele captou ninguém sabe onde, quer nesse estilo que se chama grande e sublime e que não tem em absoluto nenhum modelo na natureza, quer nas ações e nos movimentos das figuras, tão distantes das ações e dos movimentos reais. Vedes de fato, meu amigo, que se trata da querela da prosa e da poesia, da história e do poema épico, da tragédia heroica e da tragédia burguesa e da comedia gaia. "130 
A pintura de Chardin possuiu outras qualidades e seus efeitos mágicos acrescentam a percepção de outras relações entre o sentir e a verdade e remetem a questão do entendimento.

"Não se entende nada dessa magia. São camadas espessas de cores aplicadas umas em cima da outra cujo efeito transpira de baixa para cima. Outras vezes, a gente diria que é um vapor que foi soprado na tela, em outro lugar, uma espuma leve que foi jogada lá. (...) Aproxima-se, tudo se mistura, achata-se e desaparece; afasta-se, tudo se recria e se reproduz.

O sentido da visão e os seus hábitos é especialmente solicitado pelo filósofo na sensação do natural e na percepção da verdade. Diderot aponta aqui os problemas da falsidade da pinturas

"Para olhar os quadros dos outros, parece que eu preciso me fazer olhos, para ver aqueles de Chardin, eu só preciso guardar aqueles que a natureza me deu e de me servir bem deles.

"É esse daqui que entende da harmonia das cores e dos reflexos. O Chardin! não é branco, não vermelho, preto que você esmaga na sua paleta: é a substancia mesma dos objetos, é o ar e a luz que você apanha na ponta do pincel e que você amara sobre a tela."

O elogio de Chardin, pintor do gênero pobre, ganha ainda mais importância quando essa qualidade do Belo se perde na pintura detrimento de embelezamento. Diderot busca explicações para essa situação da escola francesa de pintura francesa.

"Portanto, a verdade de natureza se esqueça, a imaginação se encha de ações, de posições e de figuras falsas, aprontadas, ridículas e frias. Elas são armazenadas lá e elas sairão de lá para se apegar na tela. Todas às vezes pegaram os seus lápis ou o seu pincel, esses sombrios fantasmas acordarão, se apresentarão a ele; ele não poderá se distrair deles, e será um pródigo se ele consegue a exorcizá-los para os expulsar da sua cabeça. Eu conheci um jovem cheio de gosto, que antes de jogar qualquer traço na tela, se ajoelhava e dizia "Meu Deus, livre-me do modelo". Se é raro hoje de ver um quadro composto de um número de figuras, sem reencontrar nelas, aqui ou ali, algumas dessas figuras, posições, ações, atitudes acadêmicas que desagradam até morte um homem de gosto, e que só podem se impor àqueles por quem a verdade é estrangeira, acuse disso o eternal estudo do modelo na escola!" 31

31 DIDEROT Denis: Oeurres Complètes. Salons de 1763 e 1765. Op. cit.
Nos Ensaios sobre a pintura Diderot aponta o modelo acadêmico como causa da perda de verdade de natureza. No Salon de 1767, Diderot precisa a sua ideia.

Ninguém além de você, meu amigo, lerá esses papéis, assim posso escrever tudo o que me deleita. Esses sete últimos anos passados na Academia a desenhar segundo o modelo, você acredita que eles foram bem empregados; e você quer saber o que eu penso disso? É o que é, e durante esses sete penosos e cruéis anos, que se toma a maneira no desenho. Todas essas posições acadêmicas, constrangidas, aprontadas, arranjadas; todas essas ações friamente e desajeitadamente exprimidas por 
32 DIDEROT Denis: Oeuvres Complètes. Salons de 1763, 1765 e 1767. Op. cit.
33 Encyclopédie ou Dictionnaire raisonné des Sciences, des Arts et des Métiers. <http://portail. atilf.fr/encyclopedie/Formulairede-recherche.htm>. um pobre diabo e sempre do mesmo pobre diabo contrato em vir três vezes por semana para se desvestir e se amanequinar para um professor, o que elas têm de similar com as formas da natureza? O que que tem de similar entre um homem que tira água no poço do seu pátio e aquele, que não tendo o mesmo fardo a tirar, simula desajeitadamente essa ação, com seus dois braços para cima, no estrado da escola? O que que tem de similar aquele que finge de morrer lá com aquele que expira na sua cama, ou que se abate na rua? O que há de similar entre o lutador de escola e aquela do meu bairro? Esse homem que implora, que reza, que dorme, que reflita, que desmaia com discrição, o que há de similar com o caipira deitado na terra de cansaço e o filósofo que medita perto do fogo com o homem abafado que desmaia nomeio da multidão? Nada, meu amigo, nada. (...) ${ }^{32}$

Para Diderot, é a escolha do modelo acadêmico que é criticada, por sua teatralidade obrigatoriamente posada, falsa, afetada, ridícula, fria de suas "posições acadêmicas" amaneiradas. Basta Diderot criticar a escolha do modelo proposto pela academia para pôr em questão todo o ensino das escolas. Para ele, o modelo selecionado pela Academia mantém a conveniência nas suas regras gerais de verossimilhança, mas compromete a "verdade de natureza" porque não tem nada de natural. Diderot ressalta a importância da confrontação entre o belo e o feio, o bem e o mal. A ideia da pintura de Diderot propõe um belo fora de mim e defende um modelo externo (a natureza comum) em relação a um interno (inventado e imaginado) e arranjado segundo regras. No mesmo texto, Diderot indica aos jovens pintores lugares para a escolher de modelos

(...) Cem vezes eu tentei dizer aos jovens alunos que eu encontrava no caminho do Louvre, com as suas pastas embaixo do braço: "Meus amigos, há quanto tempo que vocês desenham lá? Dois anos. Bem, é mais do que é preciso. Deixem essa butique de maneira. Vão aos Cartuxos; e vocês verão lá verdadeira atitude, da piedade e da compunção"(...)

Não são as práticas do desenho e da pintura que estão em questão, mas o modelo que o pintor se propõe a tratar. A "verdade de natureza", como a maneira, é antes de tudo uma questão de eleição do modelo. Não se pode ter "verdade de natureza" se o modelo selecionado não é natural.

\section{Modelo, verdade de natureza e embelezamento: 0 belo clás- sico e a maneira antiga de Vien}

"MODELO, (pintura). Chama-se modelo em pintura tudo que os desenhistas, pintores, escultores se propõem a imitar. Chama-se mais particularmente modelo um homem que se põe nu nas academias, ou em casa na atitude que se quer e conforme o qual os pintores pintam ou desenham e os escultores modelam em relevos ou esculturas, em argila ou cera. Diz-se posar o modelo, é o professor do mês que posa o modelo na academia (Ver Academia). Modelo se diz ainda das figuras que os escultores modelam conforme o modelo da Academia e daquelas que eles têm em casa de qualquer material que estejam para executar segundo elas"(...) ${ }^{33}$ 
34 Livrete do Salon de 1763 acessível no site: <www.bnf.fr>.

35 NOLLI Carlo: Le pitture antiche d'Ercolano e contorni incise con qualche spiegazione: tomo terzo Napoli: nella Regia Stamperia, 1762.

Figura 3: Joseph Marie Vien - A vendedora de amores, 1763. Oléo sobre tela $98 \mathrm{~cm} \times 122 \mathrm{~cm}$. Museu do Louvre. Fonte: <collections.louvre.fr/ark:/53355/cl010057666>, disponível em 14-junho-2021.
Outro pintor elogiado por Diderot no Salon de 1763 é o pintor de história nobre Joseph Marie Vien. Esse elogio das telas ditas «à la grecque (à grega) » de Vien pode surpreender pelas suas diferencias de gênero e de maneira em relação à pintura de Chardin mas assinala a versatilidade do gosto do filosofo. Sobre "A Vendedora de amores", o livrete do Salon de 1763 menciona a relação de Vien com seu modelo: "a narração de um quadro encontrado em Herculano e que pode ser visto no gabinete do Rei das duas Sicílias em Portici. Esse quadro antigo foi gravado depois no terceiro volume das pinturas desta cidade". 34

O livrete, como era de costume, não conta história pois se trata visivelmente de uma cena sem história. O modelo não é uma narrativa, mas uma pintura, e o que nela é histórico como sujeito, composição, maneira e no tratamento.

Essa pintura acumula modelos, o narrativo, o original ou a sua reprodução: a imagem original e suas reproduções determinam a fortuna do modelo no tempo. A gravura e a narração mencionadas no livrete de 1763 são tiradas do livro de Carlo Nolli35: trata-se de uma gravura executada em 1762 representando um afresco descoberto em Herculano em 1748.

Com essa tela de Vien, Diderot discute outras qualidades do Belo e destaca a percepção de outras relações presentes desta vez na pintura de gênero nobre.

"Os quadros que Vien expos esse ano são todos do mesmo gênero, e como tem quase todos do mesmo mérito, só há um elogio a fazer sobre eles: é a elegância das formas, a graça, a ingenuidade, a inocência, a delicadeza, a simplicidade, e

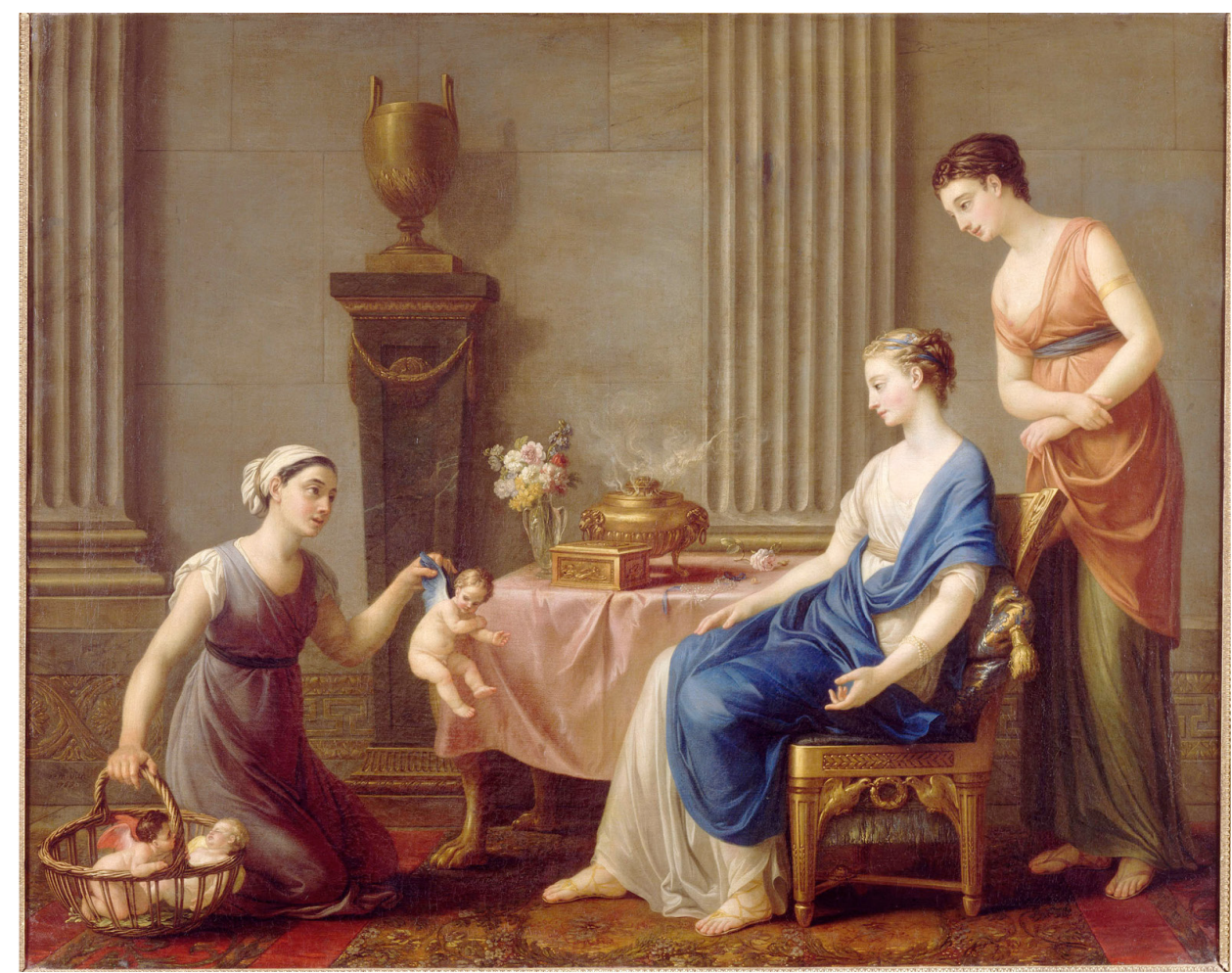


36 DIDEROT Denis: Oeurres Complètes. Salons de 1763, 1765 e 1767. Op. cit.

37 DIDEROT Denis: Oeurres Complètes. Salons de 1763, 1765 e 1767. Op. cit.

Figura 4 (esq.): Joseph-Marie VIEN. Glycère ou a vendedora de flores ou ainda a Primavera, 1763, óleo sobre tela $72 \mathrm{~cm} \times 68 \mathrm{~cm}$. Coleção privada. Paris. Fonte: <utpictura18.univ-amu. fr/notice/7079-glycere-marchandefleurs-version-troyes-vien>, disponível em 14-junho-2021.

Figura 5 (dir.): Joseph-Marie VIEN, Duas mulheres no banho.1763 Óleo sobre tela $92,3 \mathrm{~cm} \times 67,9 \mathrm{~cm}$ Museu de Cahors Henri Martin. Fonte: <https://fr.wikipedia.org/ wiki/Fichier:Deux_femmes_au_ bain_Joseph-Marie_Vien_musée_de_Cahors_Henri-Martin_ Ca.1.32.jpg>, disponível em 14-junho-2021. tudo isso juntado à pureza do desenho, a bela cor, a macieza e a verdade das carnes. Ficaríamos muito embaraçados no escolher entre a sua "Vendedora se embelezando", a sua "Vendedora de flores", a sua "Mulher saindo do banho", a sua "Sacerdotisa que queima incenso em um tripé", "A Mulher que rega as suas flores", a "Proserpina que orna o busto da sua mãe Ceres" e a sua "oferenda no templo de Vênus". Como tudo isso cheira a maneira antiga! (...) Esses quadros são pequenos, a maior não tendo senão três pés de altura por dois de largura, mas o artista mostrou bem na sua Santa Genoveva do último salão, o seu ĺcaro que está na academia, e outras pinturas que ele podia tentar com grandes composições e ter nelas sucesso. (...)"136

"(...) E depois, é toda uma elegância nas atitudes, nos corpos, nas fisionomias, nas vestes; há tranquilidade na composição, a finura!... Há tanto encanto em toda parte que é impossível de descrevê-los. Os acessórios têm aliás um gosto primoroso e um acabamento preciosíssimo. Essa pintura é em seu tudo de uma execução belíssima, a figura sentada está drapejada (drapeada) (vestida) como a antiga; a cabeça é nobre, cre-se-a fraca em expressão, mas não é está a minha opinião. Os pés e as mãos estão feitos com o maior cuidado. A poltrona é de um gosto que impressiona, (... (137 $^{137}$
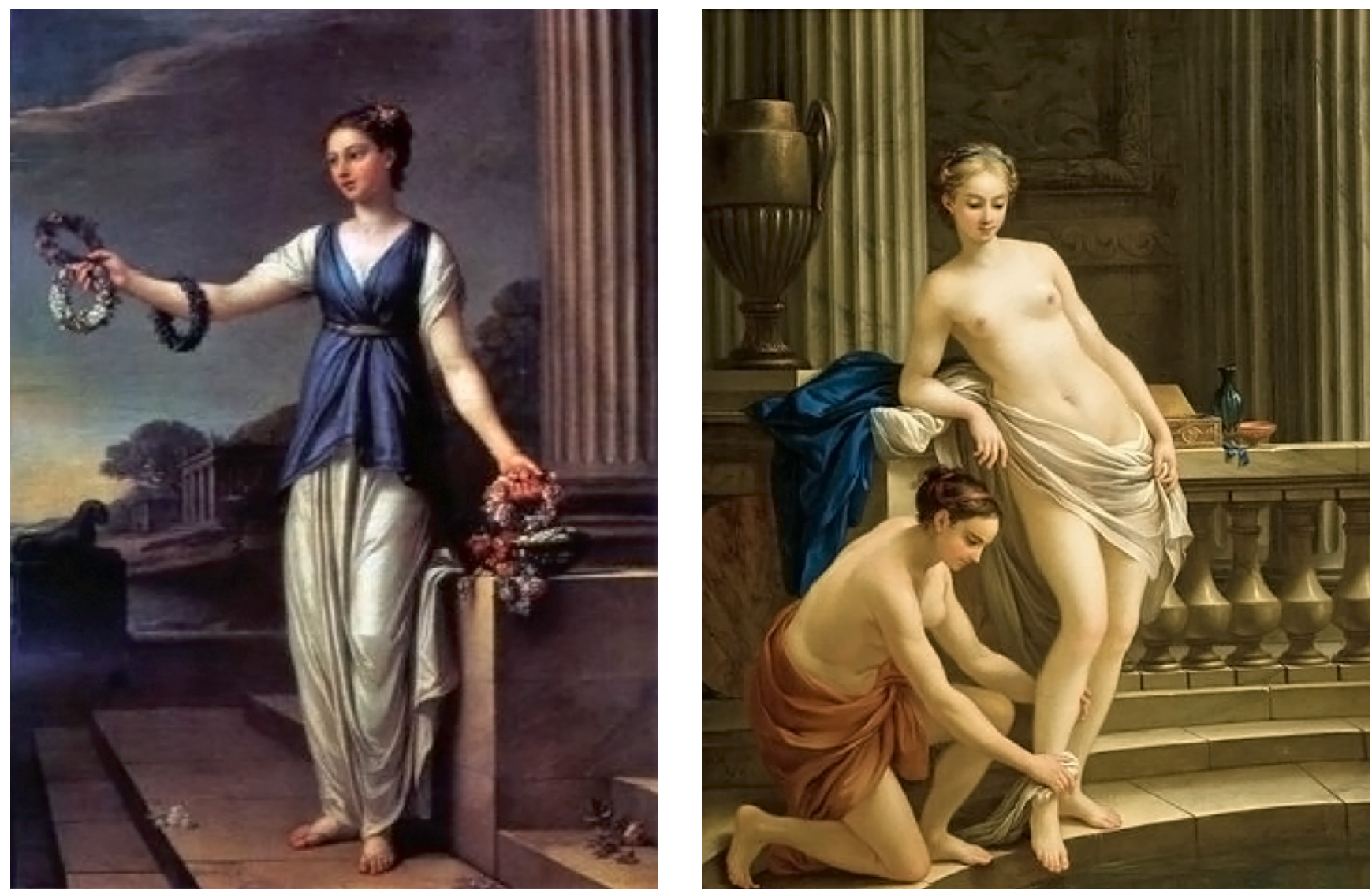

riSCO. 2021_Edição Temática "Tratados da Arte" 
38 Encyclopédie ou Dictionnaire raisonné des Sciences, des Arts et des Métiers. Op. Cit

39 "ESCOLHA: Há na pintura, como na escultura escolha de sujeito, escolha de composição, escolha de atitude. A beleza da escolha de um sujeito depende da justeza das suas relações com as circunstâncias, com o tempo para o qual ele está feito, os lugares onde ele está colocando e as pessoas que o mandaram fazer. Escolher nada tem a ver com o executar seja na pintura, seja na poesia: um sujeito pode ser muito, muito bem escolhido, e muito mal tratado. Diz-se que há num quadro uma bela escolha de composição quando o pintor apreende no sujeito que ele se propõe de representar o instante mais conveniente e os objetos que podem o caracterizá-lo melhor; uma escolha de atitude, quando as figuras se apresentam sob belos aspectos, assim prefere-se ver um rosto de mulher quando ele é belo do que a parte de trás de sua cabeça. Os professores das academias, curiosos da reputação que dá o talento do que se chama "bem posar o modelo", prejudicam consideravelmente os estudantes pela atenção que eles negam na simples apresentação desses lados da escolha, eles os impedem de conhecer e consequentemente de usar outros aspectos sob os quais a natureza se apresenta o mais frequentemente, e os reduzem a um número pequeno de atitudes que, embora variadas, trazem sempre um caráter de uniformidade bem mais desagradável numa composição do que seriam essas atitudes rejeitadas que o mestre afeta deixar ignoradas aos seus alunos. A palavra "escolha" se usa para o bem como para o mal e reprovase mais frequentemente a má escolha do que elogia o belo." Encyclopédie ou Dictionnaire raisonné des Sciences, des Arts et des Métiers.op.cit.

40 "INGENUIDADE: Sinceridade, franqueza, singeleza, ingenuidade (sinônimos). A sinceridade impede de falar coisa diferente do que se pensa, é uma virtude. A franqueza faz falar como se pensa, é um efeito do natural. A singeleza faz dizer ... continua na próxima página
Nas obras de Vien, Diderot menciona em primeiro lugar a elegância.

"ELEGÂNCIA: (substantivo feminino) (Belas Letras). Conforme alguns essa palavra vem de electus; escolhido; não se vê nenhuma outra palavra que possa ser a sua etimologia; de fato, há escolha em tudo o que é elegante. A elegância é o resultado da justeza e do deleite. Emprega-se essa palavra na escultura e na pintura. Opunha-se elegans signum a signum rigens; uma figura proporcionalizada, cujos contornos arredondados eram expressos com maciez, (oposta) à uma figura rígida demais e mal acabada. Mas a severidade dos primeiros romanos deu a essa palavra, elegantia um sentido detestável. Encaravam a elegância em todos os gêneros como uma afetação, como uma polidez rebuscada, indigna da gravidade dos primeiros tempos. ${ }^{38}(\ldots)$

A elegância é o resultado das boas e belas escolhas ${ }^{39}$, determinadas pelo "grande gosto" do pintor sensível as qualidades da graça, da ingenuidade ${ }^{40}$, da inocência ${ }^{41}$, da delicadeza ${ }^{42}$, da simplicidade ${ }^{43}$ e que possuía" a pureza no "desenho, a bela cor, a macieza e a verdade das carnes". Essas palavras, empregadas varias vezes, exaltam preceitos estéticos que ocupam os debates da Academia Real de pintura desde a sua criação no século XVII. Articulados com sucesso nas pinturas expostas por Vien em 1763, esses preceitos remetem ao sentimento do Belo da tradição clássica. Diderot aprecia esse pintura classificada como "Maneira antiga" que busca na história da pintura o entendimento de qualidades do Belo de ordem culturais mencionadas no Tratado do Belo (como por exemplo: a ordem, o caos, a grandeza, a perfeição, a simetria, a equilíbrio, a harmonia) como "habitus" de percepção.

(...) "Qualquer que seja o ser que julgamos, os gostos ou desgostos excitados pela instrução, pela educação, pelo preconceito, ou por uma certa ordem factícia em nossas ideias, todos são fundados na nossa opinião de que esses objetos têm alguma perfeição ou defeito em suas qualidades, para cuja percepção temos sentidos ou faculdades intelectuais. Oitava fonte de diversidade. "(...) ${ }^{44}$

Essa busca do Belo se articula na invenção de uma natureza idealizada e embelezada ${ }^{45}$ isto é, os acrescidos trazidos pelo pintor à natureza na sua representação pictórica. Se Vien "não faz nada do que é nem do que pode ser" e afasta assim a sua pintura da "verdade de natureza", exaltada nas telas de Chardin, o embelezar (de Vien) também procura interessar ${ }^{46}$, agradar ${ }^{47}$ e tornar precioso ${ }^{48}$. Com a fórmula "Há entre a verdade e a sua imagem a bela mulher individual que ele escolheu como modelo", Diderot aponta outra dimensão da verdade em pintura que ele situa na escolha do modelo. Pois é de verdade e de entendimento do mundo que é sempre questão na reflexão de Diderot. Diderot aprecia a qualidade cognitiva da escolha feita nas imagens lembradas (memoria) pelo artista do seu modelo. Com essa representação de uma imagem histórica de Pompeia, Diderot retoma a tópica de Zeuxis trocando o critério natural da observação das mulheres pela escolha das mais belas partes de cada uma delas pelo conhecimento e a conformidade ao antigo. As pinturas "à la Grecque" de Vien, despertam em Diderot relações históricas e estéticas (de grandeza, simetria, equilíbrio, harmonia citadas no Tratado do Belo como "hábito"). A percepção dessas relações produz um sentimento de prazer na sua contribuição ao entendimento da história da pintura e da história e da filosofia do gosto europeu no século XVIII. 
... continuação da nota $40 \ldots$

livremente o que se pensa, isto vem algumas vezes de um defeito de reflexão. A ingenuidade faz confessar o que se sabe e que se sinta, é frequentemente uma besteira. Um homem sincero não quer se enganar. Um homem franco não saberia dissimular. Um homem singelo não é em nada adequado a lisonjear. Um ingênuo nada sabe esconder. A sinceridade é o maior mérito no comercio do coração. A franqueza facilita o comercio dos negócios civis. A singeleza faz frequentemente faltar à polidez. O ingênuo faz pecar contra a prudência. O sincero é sempre estimável, o franco agrada tudo mundo. O singelo as vezes ofensa. O ingênuo se trai." Encyclopédie ou Dictionnaire raisonné des Sciences, des Arts et des Métiers. Op.cit.

\section{Conclusão}

Buscamos nesse trabalho destacar a importância da crítica de arte de Diderot como gênero literário que contribua ao lado dos textos filosóficos no questionamento recorrente dos hábitos estéticos, palavra que ele mesmo define na Encyclopédie.

"Hábito: é uma inclinação adquirida pelo exercício dos mesmos sentimentos ou pela repetição frequente das mesmas ações. O hábito instrui a natureza, ele a altera; dá energia aos sentidos, facilidade e força aos movimentos do corpo e às faculdades do espírito, enfraquece a pontada da dor. Por ele, o mais amargo absinto não há de parecer mais do que insípido. Dos objetos que a imaginação havia embelezado, o hábito priva uma parte dos encantos, dá o justo valor a bens cujo mérito nossos desejos haviam exagerado, e, se desgosta, é porque desengana. O hábito torna o gozo insípido e a privação cruel. " 49

" Eis minhas críticas e meus elogios. Louvo, censura conforme minha sensação particular que não é lei. Deus só pediria de nós a sinceridade com nós mesmos. Os artistas quererão não ser mais exigentes. Logo se diz, isso é belo, isso é ruim, mas a razão do prazer ou do desgosto se faz as vezes esperar e eu sou comandado por um diabo de homem que não lhe dá o tempo de vir. Rezam pela conversão desse homem e a testa inclinada na frente das portas do Salon, retratam-se dos julgamentos que eu vou dirigir à Academia»

Denis Diderot Salons de 1767.

\section{Continuação das notas}

41 "INOCÊNCIA: (substantivo feminino) Só as almas puras podem entender bem o valor dessa palavra. Se o homem malvado chegasse a conceber os encantos que ele exprime, ele se tornaria no momento um homem justo. A inocência é a reunião de todas as virtudes, a exclusão de todos os vícios de quem é que chegou na idade dos quarenta anos com a inocência que ele trouxe ao nascer, não preferiria morrer a alterá-la com a mais leve das faltas? Infelizes que somos, não nos sobra inocência o bastante para sentir o preço dela! Malvados juntam-se, conjuram contra ela, e há uma doçura secreta que nunca lhe roubara. Você arranca lágrimas dela, mas você não fará entrar o desespero no seu coração. Você a assombrara com calúnias, você a banira da sociedade dos homens, mas ela irá embora com o testemunho que ela se entregara a si mesma e é de você que ela terá pena na solidão, na qual você a terá constrangido de se esconder. O crime resiste ao aspecto do juiz: ele enfrenta o terror dos tormentos; o encanto da inocência o perturba, o desarma e o confunde; é o momento da sua confrontação com ela que ele teme, ele não pode aguentar o seu olhar, ele não pode ouvir a sua voz; várias vezes ele se perdeu nele mesmo para salvá-la. Oh inocência! O que aconteceu com você? Ensina-me o local da terra em que você habita para que eu vá procurá-la: sitis arida postulat undam,e vocat unda sitim. Não esperarei o último momento para sentir a sua falta." O artigo é de Denis DIDEROT. Encyclopédie ou Dictionnaire raisonné des Sciences, des Arts et des Métiers. Op.cit.

42 "DELICADEZA: Diz-se em pintura uma delicadeza de pincel, uma delicadeza de expressão, para dizer os traços nas figuras que exprimem sem ser por demais marcados, o verdadeiro, o natural da atitude e do jeito da cabeça que a pessoa deve ter quando desempenha a ação representada no quadro. Quando se diz (feito) obtido com delicadeza, essa expressão tem relação com o espírito." DOM PERNETY: Dictionnaire portatif de peinture, sculpture et gravure. Paris, 1757. Librairie Bauche. (Documento digital).

43 "SIMPLICIDADE: Sabedoria e bom gosto na escolha dos jeitos da cabeça, das atitudes e dos ajustes das figuras. Ela consiste a não pôr nisso afetos, nem de traço nacional, mas em seguir e representar a natureza simples e sem sobrecarga. Essa simplicidade foi muito negligenciada pelos artistas modernos, embora tão estimada pelos entendidos. Querendo se afastar da frieza do Antigo, caia-se no vício oposto. Mas graças a alguns, reconsideraram-se esses panejamentos esvoaçantes, esses ornamentos insípidos que se espalhavam 
com profusão e essas atitudes afetadas dos pequenos mestres e pequenas mestras que chocavam um espectador sensato. É na busca do pitoresco que esses artistas sem gênio encontraram o extravagante." DOM PERNETY: Dictionnaire portatif de peinture, sculpture et gravure. Paris, 1757. Op.cit.

44Tratado do Belo. Op.cit.

45 "EMBELEZAR é acrescer com arte a objetos que seriam talvez indiferentes por eles mesmos, formas ou acessórios que os tornam interessantes, agradáveis, preciosos, etc." Encyclopédie ou Dictionnaire raisonné des Sciences, des Arts et des Métiers. Op.cit.

46 "INTERESSE: (literatura) o interesse numa obra de literatura nasce do estilo, dos incidentes, dos caracteres, da semelhança e da sucessão. Imagina as situações as mais patéticas; se elas são mal trazidas, você não interessara. Conduz o seu poema com toda arte imaginável, se as situações são frias nele, você não interessara. Saiba encontrar situações e fazê-las se suceder; se falta a você o estilo que convém para cada coisa, você não interessara. Saiba encontrar as situações, ligá-las, colori-las; se a semelhança não está no tudo, você não interessara. Pois você será semelhante apenas se conformando a ordem geral das coisas, quando ele se agrada combinando incidentes extraordinários. Se você é apegado à pintura da natureza comum, mantém em todos os lugares a mesma proporção que reina nela. Se você se eleva por cima dessa natureza, e que seus seres estejam poéticos, aumentados que tudo seja reduzido ao módulo que você terá escolhido, e que tudo seja acrescido na mesma proporção, seria ridículo de fazer um ramo de pequenas espigas, tal como eles cruzam nos nossos campos, embaixo do braço de uma Ceres, a quem teria tido se dado sete a oito pés de altura." (...) O artigo é de Diderot. Encyclopédie ou Dictionnaire raisonné des Sciences, des Arts et des Métiers. Op.cit.

47 "AGRADÁVEL, GRACIOSO, considerados gramaticalmente. A atitude e as maneiras, diz Senhor o Abade Girard, tornam gracioso. O espírito e o humor tornam agradável. Gosta-se do encontro de um homem gracioso; ele agrada. Busca-se a companhia de um homem agradável: ele diverte. As pessoas polidas são sempre graciosas. As pessoas alegres são ordinalmente agradáveis. Não é o bastante para a sociedade de ser de um acesso gracioso, e de um comércio agradável. Faz-se uma recepção graciosa. Tem-se uma conversação agradável. Parece que os homens são graciosos pela atitude e as mulheres pelas maneiras. 0 gracioso e o agradável não significam sempre qualidades pessoais. O gracioso se diz às vezes do que bajula os sentidos e o amor-próprio, e o agradável, do que convém ao gosto e ao espírito. É gracioso ter belos objetos na sua frente, nada é mais agradável que a boa companhia. Pose-se perigoso de aproximar do que é gracioso e de usar do que é agradável. Nasce-se gracioso e se faz o agradável." O artigo é de Diderot. Encyclopédie ou Dictionnaire raisonné des Sciences, des Arts et des Métiers. Op.cit.

48 "PRECIOSO: Adjetivo (Gra-mática) que é de um grande preço. Assim se diz de bela pedra, que ela é preciosa; de um pedaço de história natural que mostra algum acidente particular, que ele é precioso; de uma pintura, que nela o colorido é precioso; de um grande ministro, que é uma preciosa vida ao estado; de uma expressão rebuscada demais, que ela é preciosa; de uma mulher que tem o hábito dessas expressões que ela é uma preciosa." O artigo é de Diderot. Encyclopédie ou Dictionnaire raisonné des Sciences, des Arts et des Métiers. Op. Cit.

49 Encyclopédie ou Dictionnaire raisonné des Sciences, des Arts et des Métiers. Op.Cit. O verbete é de Diderot. 